\title{
O IMATERIAL: conhecimento, valor e capital
}

\author{
Por Valdenize Tiziani*
}

GORZ, Andre. O imaterial: conhecimento, valor e capital. Tradução de Celso Azzan Júnior. São Paulo: Annablume, 2005. 107 p. 14 cm x $21 \mathrm{~cm}$. [Título original: L'immatériel: connaissance, valeur et capital].

Apesar de o original ter sido publicado em 2003, esse livro de André Gorz é atual e necessário, particularmente diante dos desafios da crise da economia mundial em curso. Ele remete o leitor para reflexões relevantes sobre as relações de trabalho, o conhecimento e o capitalismo.

A crise atual está gerando uma legião de desempregados, fenômeno de grande impacto observado especialmente nos EUA, no Japão, na Europa e em países emergentes, como o Brasil. A leitura de Gorz leva a crer que as demissões são decorrentes do subconsumo e também que estão vinculadas ao oportunismo do momento para resolver um problema que se arrasta há mais tempo: o capital precisa cada vez menos de trabalho de produção material. Aliás, Gorz explicitamente prevê esta crise no capítulo II, quando afirma, também, que o capitalismo cognitivo é a crise do capitalismo.

O autor, austríaco radicado na França, respeitado estudioso da sociedade contemporânea, assinou 16 obras, entre elas Misérias do presente, riqueza do possivel (2004) e Crítica da divisão do trabalho (2001), ambas traduzidas para o português.

\footnotetext{
* Pesquisadora colaboradora do Centro de Desenvolvimento Sustentável da Universidade de Brasília, professora da Universidade Estadual Vale do Acaraú, no Estado do Ceará, doutora em Anatomia Patológica pela Universidade Estadual de Campinas (Unicamp). Email:vtiziani@gmail.com
} 
O tema central é desenvolvido em quatro capítulos: "O trabalho imaterial", "O capital imaterial", "Rumo a um comunismo do saber?...", “....Ou rumo a uma civilização pós-humana?” Ao longo dos três primeiros tópicos, o autor discute as conseqüências da economia do conhecimento, como uma forma de capitalismo que busca redefinir as suas características de trabalho, valor e capital e incluir novos domínios.

No primeiro capítulo, o autor fundamenta as suas concepções do "imaterial". Discorre elegantemente sobre as atuais relações de trabalho, nas quais o capital fixo material vem sendo substituído pelo capital humano, pelo "imaterial", pelo trabalho complexo, imensurável. O conhecimento, como força produtiva principal, foi previsto desde Marx. Gorz reconhece que a ciência e as artes no tempo livre dos indivíduos são colocadas a serviço da produção. Ele compara o trabalhador taylorista, destituído de saberes cotidianos, transformado em um autômato da produção material, com o pósfordista, para quem o essencial não são as competências profissionais, mas as habilidades sociais, as qualidades de comportamento, expressivas e imaginativas, a capacidade de improvisação e de cooperação, todas adquiridas fora do ambiente de trabalho. Portanto, o autor observa que as empresas consideram como "seu" capital humano o que é, de fato, um recurso gratuito, uma externalidade que não é individual, mas essencialmente coletiva (p. 20). Explora, ainda, o aspecto da "mobilização total das capacidades e das disposições, inclusive as afetivas" (p. 22). "Não é mais o sujeito que adere ao trabalho, mas o trabalho que adere ao sujeito" (p. 22). Os colaboradores tenderão a explorar as suas capacidades fora do trabalho, numa auto-afirmação de que podem mais do que realizam profissionalmente.

Esse modelo vigente tende a minorar as diferenças entre sujeito e empresa, forçando o indivíduo a ser uma empresa: um capital fixo que exige ser continuamente modernizado, ampliado e valorizado. 
Assim, o regime salarial deve ser abolido e as empresas diminuem os seus efetivos, terceirizando para os auto-empreendedores, sem assumir compromissos com a saúde ou com a aposentadoria dos prestadores.

Na opinião do autor, a visão neoliberal do trabalho contempla a "abolição do regime salarial, o auto-empreendedorismo generalizado, e a subsunção de toda a pessoa e da vida, pelo capital" (p. 25). Esta visão ignora que o trabalho independente está sob o jugo de um único grande grupo ou de poucos grupos que submetem estes empreendedores a períodos alternados de hiper-atividade ou desemprego. Na sociedade "pós-salarial", o desemprego também desaparece. Se há desempregados é porque a empregabilidade deles está em falta e compete a eles restaurá-la, adquirindo competências mais vendáveis do que as que têm (p. 26).

Desenvolve-se, então, a reivindicação da renda da existência, incondicional e suficiente, que permita desenvolver atividades sociais ou culturais não-mensuráveis pela sua rentabilidade. Gorz entende, entretanto, que esta somente tem sentido se for contrária a um valor-trabalho,

se não exige nem remunera nada: sua função, ao contrário é restringir a esfera de criação de valor no sentido econômico, tornando possível a expansão de atividades que não criam nada que se possa comprar, vender, trocar por outra coisa; ou seja, nada que tenha valor (no sentido econômico) mas apenas riquezas que têm valor intrínseco. (p. 27)

Desta maneira, ele defende a renda que permita o "desenvolvimento pleno e incondicional das pessoas" (p. 27), o acesso à cultura e ao saber, sem atrelamento à utilidade para a produção, sem que o capital se aproprie dele e o intrumentalize (p. 27, citando Marx, 1953). Vê a sociedade não como um modo de produção, mas entende que as pessoas precisam ser livres para poder refletir as mudanças que nela se operam, tendo um sentido intrínseco, independente do capital. 
No segundo capítulo, Gorz discorre sobre o capital imaterial. Parte da tese de que a expressão "economia do conhecimento" significa transtornos para o sistema econômico, pois indica que o conhecimento tornou-se a principal força produtiva e que o valor das mercadorias é determinado pelo conjunto de conhecimento e inteligências, tornando-se a principal forma de trabalho e do capital, ainda que imensuráveis. Em economia, não existe valor sem grandeza e não se pode valorar o que não se pode produzir nem permutar. Portanto, o conhecimento, por não poder ser expresso em unidades de valor, inviabiliza a sua avaliação como capital. No entanto, o sistema fará o conhecimento funcionar como um capital, forçandoo a economizar mais trabalho do que custou e incorporando-o nas mercadorias que com ele se produzem, tornando-o propriedade exclusiva da empresa que o valoriza.

Gorz elabora o conceito de capital imaterial, definindo melhor o que distingue conhecimentos e saberes, e denuncia a bolha financeira que vivenciamos. Discute com precisão a função da publicidade na desconstrução do interesse comum e da cidadania. Aborda a submissão da ciência ao capitalismo e as suas consequências nefastas. Qual é a saída, então? O autor destaca uma

\footnotetext{
"segunda" economia não formalizável, invisível, sem a qual a primeira economia reinante não poderia surgir nem perdurar. Ela abrange todas as relações e realizações não computáveis e não remuneráveis, cuja motivação é a alegria espontânea na colaboração livre, no convívio e na doação livres. A primeira economia deve estar subordinada à segunda, a criação de riqueza deve ser desatrelada da criação de valor. (p. 57)
}

Será que isso é possível? Este caminho pode provocar no leitor incerteza e descrença, mas merece uma leitura e uma reflexão mais aprofundada na construção de novos ideais.

No terceiro capítulo, Gorz discute as incoerências e contradições internas do capitalismo cognitivo. Argumenta que elas 
geraram a crise do capitalismo que abala as estruturas profundas da sociedade, numa economia que não conhece outro valor que o comercial, economicizando todas as atividades e todas as riquezas, empobrecendo as relações sociais e degradando o meio ambiente. Assim, busca uma redefinição de riqueza, propondo a superação do produtivismo, no qual as forças e capacidades humanas deixam de ser meios de produzir riqueza, posto que são a verdadeira riqueza. Analisa os movimentos sociais espontâneos que evidenciam certo anarco-comunismo, denotado pelo aparecimento dos programas de computador livres, hackers, movimento via campesina, entre outros, em que redes livres são o denominador comum:

Estrutura não hierárquica em redes horizontais descentradas em vias de se auto-produzir e de se auto-organizar, fundadas no princípio da democracia consensual, segundo a qual toda proposição é levada em consideração, debatida, enriquecida e elaborada com as contribuições de todos. (p. 70)

Gorz propõe que estas redes poderão ser o esboço de um mundo diferente, se elas se difundirem no tecido social, permitindo a experimentação de modos de vida diferentes dos dogmas do capitalismo, fazendo com que estas sociedades percebam que os constrangimentos e os valores do capitalismo não são naturais, liberando novas aspirações sociais. Relaciona a sociedade do saber ao comunismo do saber, em que a criação de riqueza seria o livre desenvolvimento das aptidões humanas, do lazer e do prazer, afluindo para uma economia com sentido coletivo, uma antítese da economia política do capital.

Na última parte do livro, Gorz tece uma interessante análise do conhecimento e dos saberes. Cunha os fundamentos do movimento ambientalista, que teria nascido da resistência à apropriação privada da natureza e à destruição desse bem comum, que é o mundo vivido. Salienta que o conhecimento e o seu desenvolvimento, por meio das ciências, não se deixaram guiar pelas necessidades do mundo experimentado e ainda desqualificaram os saberes, reivindicando 
para a ciência o monopólio do conhecimento (p. 80). Os relatos deste capítulo refletem a dura crítica do autor à ciência. Na sua visão, ela passou a ser exercida de forma racional e calculista, com o objetivo de produzir uma ordem racional do mundo, erradicando as incertezas e as imprevisibilidades, eliminando a natureza interior e exterior, substituindo-a por tecnologias pré-programadas e autoreguladas. No entendimento do autor, a ação da ciência de abolir a natureza é cúmplice do "projeto do capital de substituir as riquezas primordiais, que a natureza oferece gratuitamente e que são acessíveis a todos, por riquezas artificiais" (p. 87). Exemplos são a exogênese, o mercado de esperma, de úteros, de genes, de célulastronco e de órgãos. O próximo passo seria a "mercantilização" de seres humanos "geneticamente melhorados, pós-humanos, clonados ou artificiais e de nichos ecológicos artificiais" (p. 88).

Muito embora as considerações sejam apropriadas e coerentes, a visão das possibilidades futuras relacionadas à ciência, em particular à biologia, parece demasiado negativa. A ênfase do autor reflete a necessidade de realçar os aspectos éticos e filosóficos com os quais nos deparamos e conduzir à necessária reflexão. Entretanto, não se pode desprezar o sentimento de auto-preservação da humanidade, demonstrado sempre que ela se confronta com limites extremos.

O livro é sucinto, porém denso, muito recomendável para aqueles interessados em melhor compreender o capitalismo vigente, as relações de trabalho, o papel do conhecimento, bem como as suas implicações na sociedade contemporânea.

\section{Referências}

GORZ, A. Misérias do presente, riqueza do possível. São Paulo: Annablume. 2004. 2001.

. Crítica da divisão do trabalho. São Paulo: Martins Fontes.

MARX, K. Grundisse. Berlin: Dietz Verlag, 1953. 